\title{
Antibodies and Antisense Oligonucleotide for Probing the Distribution and Putative Functions of Central 5- $\mathrm{HT}_{6}$ Receptors
}

Michel Hamon, Ph.D., Edith Doucet, Ph.D., Karine Lefevre, Ph.D., Marie-Christine Miquel, Ph.D., Laurence Lanfumey, Ph.D., Ricardo Insausti, M.D., Ph.D., Diana Frechilla, Ph.D., Joaquin Del Rio, M.D., Ph.D., and Daniel Vergé, Ph.D.

Among the recently cloned serotonin (5-

hydroxytryptamine, 5-HT) receptors, the $5-\mathrm{HT}_{6}$ subtype is of special interest for at least two reasons: 1) it is abundant in limbic areas which participate in the control of mood and emotion; and 2) some antidepressants and antipsychotics are potent $5-\mathrm{HT}_{6}$ receptor antagonists. Studies using polyclonal anti-5- $\mathrm{HT}_{6}$ receptor antibodies and an antisense oligonucleotide were performed in order to investigate further the function(s) of 5-HT 6 receptors in the rat brain. Immunocytochemistry at the light and electron microscope levels showed that $5-\mathrm{HT}_{6}$ receptors are mainly confined to the dendritic compartment, suggesting that they could mediate 5-HT actions on neuronal firing. In some limbic areas, $5-\mathrm{HT}_{6}$ receptor-like immunoreactivity is also associated with neuronal cilia with yet unknown functions. Continuous i.c.v. infusion with an antisense oligonucleotide for 3-4 days resulted in decreased 5- $\mathrm{HT}_{6}$ receptor-like immunostaining of the nucleus accumbens and anxiogenic behaviours in the social interaction and elevated plus maze tests. Selective $5-\mathrm{HT}_{6}$ receptor ligands are eagerly expected to investigate further the potential implication of these receptors in limbic-dependent behaviours. [Neuropsychopharmacology 21:68S-76S, 1999] (C) 1999 American College of Neuropsychopharmacology. Published by Elsevier Science Inc.
KEY WORDS: 5- $\mathrm{HT}_{6}$ receptor; Immunocytochemistry; Limbic areas; Dendritic compartment; Neuronal cilia; Anxiety

Extensive studies on the pharmacological properties of serotonin (5-hydroxytryptamine, 5-HT) agonists and

From the INSERM Neuropsychopharmacology Unit $288(\mathrm{MH}$ ED, LL), Faculty of Medicine Pitié-Salpêtrière, and the Department of Neurobiology of Intercellular Signals (KL, M-CM, DV), University Paris VI, Paris, France; and the Departments of Anatomy and Pharmacology (RI, DF, JDR), University of Navarra Medical School, Pamplona, Spain.

Address correspondence to: Michel Hamon, Ph.D., INSERM U288, Neuropsychopharmacology, Faculty of Medicine PitiéSalpêtrière, 91, Boulevard de l'Hôpital, 75634 Paris Cedex 13, France.

Received December 10, 1998; revised March 3, 1999; accepted March 30, 1999. antagonists for the last 40 years led to the concept of the existence of several receptors mediating the multiple functions of this neuroactive compound both in the central nervous system (CNS) and at the periphery. Binding studies with various radioactive derivatives of these molecules then provided the first direct demonstration of the presence of distinct specific receptor binding sites in brain membranes and sections (see Hoyer et al. 1994). However, the definitive demonstration of the mediation of 5-HT actions through activation of several classes of specific membrane-bound receptors was achieved by the cloning and sequencing of corresponding cDNAs. Indeed, transfection of encoding sequences into various cell lines which do not constitutively express the receptors results in the synthesis and membrane addressing of the corresponding receptor pro- 
teins, thereby making the transfected cells responsive to their specific ligands. Thanks to these molecular biology approaches, it has thus been demonstrated that 5-HT exerts its pleiotropic actions through the activation of 14 different receptor types, plus additional variants resulting from alternative splicing and/or editing of primary transcripts (see Baumgarten and Göthert 1997).

As expected, several of the 5-HT receptors isolated by molecular biology approaches actually correspond to those which were previously extensively characterized on the basis of their pharmacological and functional properties, as well as their distribution both in the CNS and at the periphery. This is notably the case of several receptor types that belong to the $5-\mathrm{HT}_{1}\left(5-\mathrm{HT}_{1 \mathrm{~A}}\right.$, $\left.5-\mathrm{HT}_{1 \mathrm{~B}}, 5-\mathrm{HT}_{1 \mathrm{D}}\right)$, the $5-\mathrm{HT}_{2}\left(5-\mathrm{HT}_{2 \mathrm{~A}}, 5-\mathrm{HT}_{2 \mathrm{C}}\right)$, the $5-\mathrm{HT}_{3}$, and the $5-\mathrm{HT}_{4}$ classes of 5-HT receptors (Hoyer et al. 1994). However, other clones do not correspond to previously characterized receptors. Among them, the 5- $\mathrm{HT}_{6}$ receptor is of special interest because it seems to be expressed (almost) exclusively in the CNS (Monsma et al. 1993; Ruat et al. 1993). Its 438-amino acid sequence in the rat is suggestive of a typical G-protein coupled receptor with seven hydrophobic domains that probably span the plasma membrane (Kohen et al. 1996; Branchek and Zgombick 1997). Indeed, pharmacological characterization of $5-\mathrm{HT}_{6}$ receptors expressed in various transfected cell lines showed that they are positively coupled with adenylyl cyclase through a functional interaction with G $\alpha$ S (Monsma et al. 1993; Ruat et al. 1993; Max et al. 1995; Branchek and Zgombick 1997). Interestingly, low concentrations of several tricyclic antidepressant and typical and atypical (i.e. clozapine-related) antipsychotic drugs affect 5 - $\mathrm{HT}_{6}$-mediated production of cyclic AMP in these cells (Monsma et al. 1993; Roth et al. 1994; Boess et al. 1997; Grimaldi et al. 1998), suggesting that $5-\mathrm{HT}_{6}$ receptors in brain might be potential targets for these psychotropic drugs. In addition, these data support the idea that selective $5-\mathrm{HT}_{6}$ receptor ligands might be endowed with specific psychotropic actions, and of potential interest for the treatment of psychiatric diseases. However, to date, little is known about the functions of central $5-\mathrm{HT}_{6}$ receptors notably because pharmacological tools for relevant investigations are quite scarce. Indeed, no selective $5-\mathrm{HT}_{6}$ agonist is yet available and selective $5-\mathrm{HT}_{6}$ antagonists with relatively high affinity have only recently been developed (Sleight et al. 1998).

In order to gain information on the possible functional roles of $5-\mathrm{HT}_{6}$ receptors in the rat brain, two different approaches have been selected in the present study: 1) the development of specific antibodies for the visualization of $5-\mathrm{HT}_{6}$ receptors at the light and electron microscope levels; and 2) the use of a specific antisense oligonucleotide to selectively inhibit the expression of $5-\mathrm{HT}_{6}$ receptors, and investigate the consequences on the rat behaviour in various paradigms.

\section{MATERIALS AND METHODS}

\section{Preparation of Affinity-Purified Anti-5- $\mathrm{HT}_{6}$ Receptor Antibodies}

A synthetic octadecapeptide (LPGEATRDPPPPTRATTV), corresponding to a portion $\left(\mathrm{Leu}^{398}-\mathrm{Val}^{415}\right)$ of the $\mathrm{C}$ terminal domain of the rat $5-\mathrm{HT}_{6}$ receptor (Kohen et al. 1996), was conjugated to keyhole limpet hemocyanin according to the protocol of El Mestikawy et al. (1990). This portion of amino acid sequence is highly selective of the $5-\mathrm{HT}_{6}$ receptor since no significant homology was found with the equivalent portion of any other serotonin receptor or with any other protein sequence available in data bases (GenBank, EMBL, SWISSPROT and Genpept databases). A white New Zealand male rabbit was immunized with $0.2 \mathrm{mg}$ of the conjugated peptide each four-weeks for six months, and blood was collected four weeks after the last injection. After clotting, the resulting antiserum was decomplemented by heating at $56^{\circ} \mathrm{C}$ for $30 \mathrm{~min}$, dialyzed extensively against $0.9 \% \mathrm{NaCl}$, and affinity purified on Affi-Gel 10 conjugated with the synthetic octadecapeptide antigen (Gérard et al. 1997). Extensive characterization of affinity purified anti-5- $\mathrm{HT}_{6}$ receptor antibodies included ELISA and immunoautoradiographic procedures (Gérard et al. 1997).

\section{Light Microscopic Immunocytochemistry}

Adult male Wistar rats were anaesthetized with pentobarbital $(60 \mathrm{mg} / \mathrm{kg}$, i.p.) and perfused via the ascending aorta with $50-100 \mathrm{ml}$ of $0.9 \%(\mathrm{w} / \mathrm{v}) \mathrm{NaCl}$ containing sodium nitrite $(1 \mathrm{~g} / \mathrm{l})$, followed by $350 \mathrm{ml}$ of $4 \%$ paraformaldehyde in $0.1 \mathrm{M}$ sodium phosphate buffer (PB), pH 7.4. Except when indicated, all steps were performed at room temperature. The brains were quickly removed and postfixed by immersion for $3 \mathrm{hr}$ in the same fixative. Brains were cryoprotected for $48 \mathrm{hr}$ with $25 \%$ sucrose containing $0.1 \%$ sodium azide in PB (with change for a fresh medium after $24 \mathrm{hr}$ ), then frozen at $-30^{\circ} \mathrm{C}$, and $30 \mu \mathrm{m}$ coronal sections were cut using a microtome (Leica) at $-18^{\circ} \mathrm{C}$. Sections were collected in

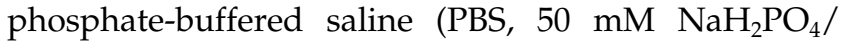
$\mathrm{Na}_{2} \mathrm{HPO}_{4}, 154 \mathrm{mM} \mathrm{NaCl}, \mathrm{pH} 7.4$ ), treated with $1 \%$ (v/v) $\mathrm{H}_{2} \mathrm{O}_{2}$ for 30 min to block endogenous peroxidase activity, and then washed with the same buffer for a further $30 \mathrm{~min}$. Free floating sections were preincubated in PBS containing $3 \%(\mathrm{w} / \mathrm{v})$ bovine serum albumin (BSA) for $30 \mathrm{~min}$ to reduce non-specific binding of the antibodies. All subsequent incubations with either primary or secondary antibodies were performed in PBS containing $1.5 \%$ BSA, with continuous gentle agitation. Sections were first incubated overnight at $4^{\circ} \mathrm{C}$ in the presence of affinity-purified anti-5- $\mathrm{HT}_{6}$ receptor antibodies (dilution 1:2000) and $0.1 \%$ Triton X-100. After extensive rinses in PBS, sections were processed using the avidin- 
biotin-peroxidase $(\mathrm{ABC})$ staining mehod. In brief, they were incubated with biotinylated goat anti-rabbit IgG (Vector, dilution 1:250) for $1 \mathrm{hr}$, washed with PBS and then exposed to the avidin-biotin-peroxidase complex (Vector, dilution 1:200) for $1 \mathrm{hr}$ (see Gérard et al. 1997 for details). After a further rinse in PBS, the peroxidase activity was finally visualized by incubating sections in $0.02 \%(\mathrm{w} / \mathrm{v}) 3,3^{\prime}$-diaminobenzidine (DAB) dissolved in $50 \mathrm{mM}$ Tris- $\mathrm{HCl}, \mathrm{pH} 7.4$, for $15 \mathrm{~min}$, and then for a further 2-5 min after the addition of $0.002 \%(\mathrm{v} / \mathrm{v})$ hydrogen peroxide to the incubating medium. Alternatively, peroxidase activity was revealed using the chromogen VIP (Vector) according to a slight modification of the protocol of Zhou and Grofova (1995). Briefly, sections were washed extensively in $0.01 \mathrm{M}$ PBS, pH 7.4, then incubated for $20 \mathrm{~min}$ in the dark with the VIP complex diluted in the same buffer according to the manufacturer's instructions. Peroxidase activity was revealed by the addition of a drop of hydrogen peroxide to the incubating medium $(5 \mathrm{ml})$, followed by a $6-15 \mathrm{~min}$ incubation. After extensive washing with PBS, sections stained with DAB or VIP were transferred to gelatin-coated slides, dried and dehydrated before being mounted with Permount under glass cover-slips.

\section{Electron Microscopic Immunocytochemistry}

Rats were anaesthetized and perfused as above except that $0.1 \mathrm{M}$ glutaraldehyde was added to the fixative. After postfixation in the same fixative without glutaraldehyde, brains were transferred to PBS and $50 \mu \mathrm{m}$ coronal sections were cut using a vibratome (Lancer). Free floating sections were then treated as above except that Triton X-100 was omitted. After development of peroxidase activity, sections were rinsed and postfixed with $2 \%$ osmium tetroxide in $0.1 \mathrm{M} \mathrm{PB}, \mathrm{pH} \mathrm{7.4}$, for $45 \mathrm{~min}$, then dehydrated in graded ethanol solutions and impregnated overnight in Epon (DAB stained sections) or Araldite (VIP stained sections) at $37^{\circ} \mathrm{C}$. Sections were flat-embedded between two silicon coated slides and the resin was allowed to polymerize at $60^{\circ} \mathrm{C}$ for $24-48$ hr. Ultrathin sections were cut with an ultramicrotome (Reichert), collected on bare 300 mesh copper grids and stained with Reynold's lead citrate for $15 \mathrm{~min}$. They were finally examined at $80 \mathrm{kV}$ with a JEOL $100 \mathrm{CK}$ electron microscope.

\section{Intracerebroventricular Infusion of Oligonucleotides}

An antisense oligonucleotide was designed against the initiation codon of the rat $5-\mathrm{HT}_{6}$ receptor mRNA. Its sequence, 5'-GCCTGGCTCTGGAACCAT-3', was complementary to nucleotides $1-18$ of the transcript. A missense oligonucleotide was used as control. The absence of homology between these oligonucleotides and any other mammalian sequence was confirmed through a search in the GenBank database using the National Center for Biotechnology Information BLAST server (Altschul et al. 1990). To improve resistance to nucleases, the oligonucleotides (Boehringer Mannheim, Germany) were phosphorothioate-modified at the two terminal bases of both $3^{\prime}$ and $5^{\prime}$ ends.

Adult male Wistar rats (260-280 g) were anaesthetized with ketamine/diazepam $(70 / 5 \mathrm{mg} / \mathrm{kg}$, i.p.) and placed in a stereotaxic frame. A cannula was implanted into the left lateral ventricle (AP $=-7.9 \mathrm{~mm}, \mathrm{~L}=1 \mathrm{~mm}$ from the interaural line; $\mathrm{H}=3.5 \mathrm{~mm}$ below the surface of the skull) and an Alzet osmotic minipump (mod. $1003 \mathrm{D}, 100 \mu \mathrm{l})$ was connected to the cannula via a polyethylene catheter. After the surgical procedure, animals were housed individually and received either the antisense or the missense oligonucleotide $(2.2 \mu \mathrm{g} / \mu \mathrm{l} ; 1 \mu \mathrm{l} /$ h) or saline $(1 \mu \mathrm{l} / \mathrm{h})$ for four consecutive days. Rectal temperature, body weight and the amount of food consumed by each animal were recorded every morning.

\section{Stereological Counting}

Two series of adjacent coronal sections $(30 \mu \mathrm{m})$ were prepared, one for light microscopic immunocytochemistry using the $\mathrm{DAB}$ technique described above and the other for Nissl staining with thionin to determine the cytoarchitectonic boundaries of the nucleus accumbens. The number and length of the cilia-like structures labelled with the anti-5- $\mathrm{HT}_{6}$ receptor antibodies in the nucleus accumbens were quantified with the C.A.S.T. Grid System (Olympus, Denmark) using a Leitz microscope. The total volume of the nucleus accumbens in the hemisphere ipsilateral or contralateral to the i.c.v. infusion was estimated by using the Cavalieri principle (Gundersen and Jensen 1987; Michel and Cruze-Orive 1988) for the unbiased quantification of arbitrarily shaped volumes. The number of immunoreactive cilia was unbiasedly estimated by optical disector systematically subsampled on each Cavalieri slice, according to well established protocols (Sterio 1984; West et al. 1996). All cilia coming into focus that were inside the limits of the disector were counted, from 3 to $13 \mu \mathrm{m}$ starting from the surface of the section. The cilia were only counted if the upper part of the cilium was inside the limits of the disector and fulfilled the rules for counting (Sterio 1984).

\section{Behavioural tests}

Rats were kept under conditions of constant temperature $\left(22 \pm 1^{\circ} \mathrm{C}\right)$, free access to food and water, and controlled lighting on a $12 \mathrm{hr}$ light/dark cycle with lights off at 8:00 PM. All experiments were carried out according to the European Community Council Directive of 24 November 1986 (86/609/EEC). Behavioural tests, al- 
ways performed during the light period (between 9:00 $\mathrm{AM}$ and 2:00 PM), were conducted in parallel in rats which had been treated with the antisense or the missense oligonucleotide, and control rats that received only i.c.v. saline under the same conditions (see above).

The social interaction test was performed as described by File (1980). Weight-matched ( $\pm 5 \mathrm{~g})$ pairs of rats, unfamiliar with each other, were placed in a black wooden open-topped box $(65 \times 65 \times 45 \mathrm{~cm}$ high $)$ under bright white light $(100 \mathrm{~W})$. Active social interaction (sniffing, walking around, mutual grooming, climbing over and crawling under partner) and number of contacts were recorded for 10 min using a digital VideomexV-system (Columbus Inst. USA). At the end of each test, the box was thoroughly wiped clean.

The behaviour of rats in the elevated plus maze was evaluated $72 \mathrm{hr}$ after initiation of i.c.v. infusion according to the procedure described by Pellow et al. (1985). The number of entries in the two open arms $(50 \times 10$ $\mathrm{cm})$ and the two closed arms $(50 \times 10 \times 40 \mathrm{~cm})$ and the total time spent in the open arms were scored for $5 \mathrm{~min}$. The maze was thoroughly wiped clean after each trial.

Spontaneous locomotor activity was measured after three days of continuous i.c.v. infusion of either the antisense oligonucleotide, the missense one or the vehicle (saline). Rats were placed in a black wooden opentopped box as above and distance traveled in $\mathrm{cm}$ was measured for two consecutive periods of $15 \mathrm{~min}$ by using a digital Videomex-V system working with the appropriate computer program (Columbus Inst., USA).

\section{RESULTS AND DISCUSSION}

\section{Immunocytochemical Distribution of $5-\mathrm{HT}_{6}$ Receptors in the Rat Brain}

Low Magnification Light Microscopy. A dense immunostaining was observed in the frontal, entorhinal and piriform cortices, the nucleus accumbens, the cerebellum, the caudate-putamen (Figure 1A), the hippocampus (particularly the dentate gyrus and the CA1 area of Ammon's horn, Figure 1B), the olfactory tubercle (plexiform layer), and the islands of Calleja (Figures 2A and B). A moderate intensity of staining was found in the other cortical zones, the taenia tecta, the substantia nigra, the oculomotor nucleus, the red nucleus, the motor trigeminal nucleus and the facial nucleus. In contrast, very low to undetectable $5-\mathrm{HT}_{6}$ receptor-like immunoreactivity was noted in the septum, the globus pallidus (Figure 1A), the hypothalamus, the colliculi and the raphe nuclei (see Gerard et al. 1997). Indeed, in the latter structures, immunostaining only slightly exceeded the background level of sections which had been incubated with preimmune serum or antibodies saturated with the synthetic octadecapeptide antigen (not shown). This distribution generally matched that
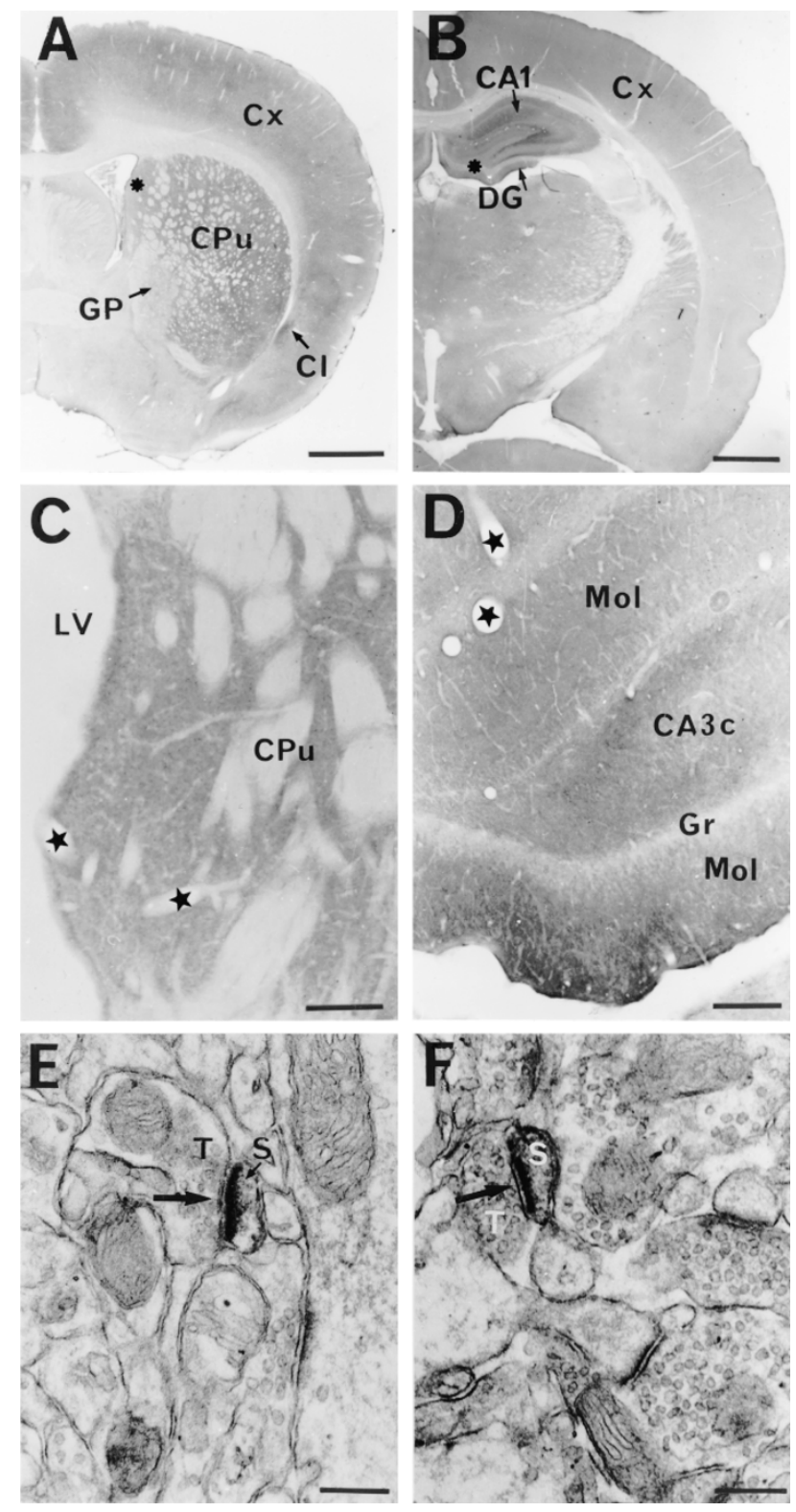

Figure 1. $5-\mathrm{HT}_{6}$ receptor immunolabeling in rat brain sections at the level of the striatum $(\mathbf{A}, \mathbf{C}, \mathbf{E})$ and the hippocampus (B, D, F). A, B: low magnification micrographs showing the $5-\mathrm{HT}_{6}$-like immunostaining in the caudate-putamen $(\mathrm{CPu})$, the dentate gyrus (DG) and CA1 area of the hippocampus, the cerebral cortex $(\mathrm{Cx})$ and the claustrum $(\mathrm{Cl})$, and the very low level of immunoreactivity in the globus pallidus (GP). C, D: high magnification of areas indicated by asterisks $\left(^{*}\right)$ in A and $\mathrm{B}$, respectively, showing that $5-\mathrm{HT}_{6}$ like immunoreactivity is located in the neuropil and absent at the level of cell bodies (LV, lateral ventricle; Mol, molecular layer, Gr, granule cell layer); blood vessels are indicated by stars. E, F: electron micrographs of dense $5-\mathrm{HT}_{6}$ immunostaining of dendritic spines (S) at the level of the postsynaptic side of synapses (arrows) with unlabelled terminals (T). Scale bars: A, B: $1.5 \mathrm{~mm}$; C, D: $200 \mu \mathrm{m}$; E, F: $0.25 \mu \mathrm{m}$. 

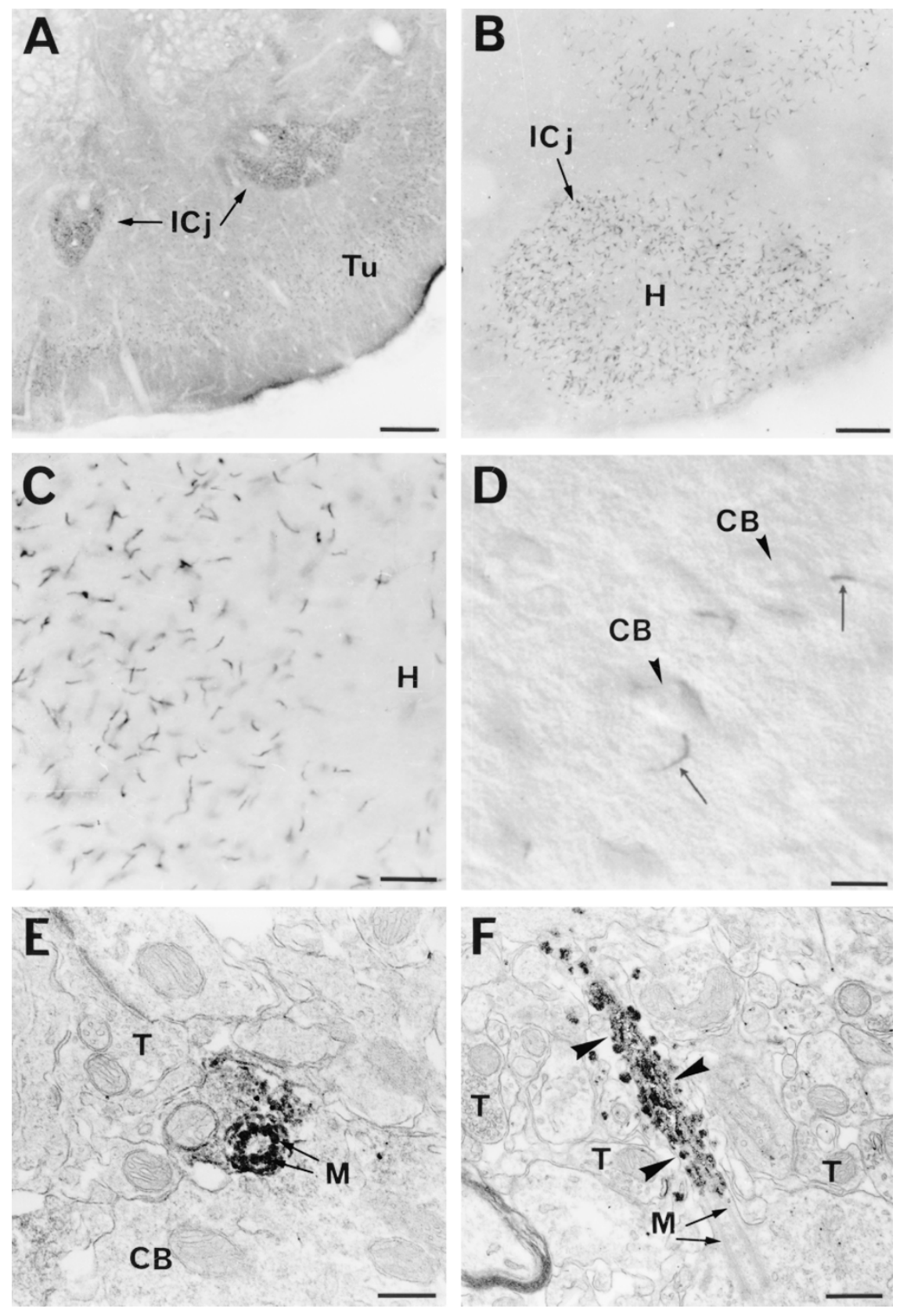

Figure 2. $5-\mathrm{HT}_{6}$ receptor immunolabeling of cilia-like processes in the olfactory tubercle and the islands of Calleja. A, B, C: light microscope immunolabeling at low and medium magnification in the olfactory tubercles (Tu; A) and the islands of Calleja (ICj; A-C). In the latter areas, immunoreactive processes are concentrated in the periphery and the hilus $(\mathrm{H})$ is almost devoid of immunolabeling. D: Nomarski interference contrast image at high magnification of immunolabeling in the islands of Calleja. Two immunoreactive processes (arrows) are emerging from cell bodies (CB, arrowheads). E, F: electron microscope immunocytochemical labeling in the islands of Calleja. Sections were processed for electron microscopy with revelation of peroxidase activity using VIP (E) or DAB (F). E: A labeled cilium-like process cut transversally shows a circular array of microtubules ( $\mathrm{M}$, arrows). F: When cut longitudinally, the labeled process (arrowheads) arising from a cell body allows the visualization of an unlabeled basal body with microtubules (M, arrows). $\mathrm{T}$ : unlabeled terminals. Scale bars: A: $200 \mu \mathrm{m}$; B: $100 \mu \mathrm{m}$; C: 20 $\mu \mathrm{m}$; D: $10 \mu \mathrm{m}$; E: $0.25 \mu \mathrm{m}$; F: $0.35 \mu \mathrm{m}$. of the $5-\mathrm{HT}_{6}$ receptor transcript (Ward et al. 1995; Gérard et al. 1996). Nevertheless, some mismatches were found. Thus, areas such as the hypothalamus, the habenula and the raphe nuclei contain significant amounts of 5- $\mathrm{HT}_{6}$ receptor mRNA (Ward et al. 1995; Gérard et al. 1996) but almost undetectable 5- $\mathrm{HT}_{6}$ receptor-like immunoreactivity. Conversely, $5-\mathrm{HT}_{6}$ receptor mRNA could not be detected in the thalamus (Ward et al. 1995) where $5-\mathrm{HT}_{6}$ receptor-like immunoreactivity was observed. In the cerebellum, low levels of 5- $\mathrm{HT}_{6}$ receptor-mRNA are found (Ward et al. 1995; Gérard et al. 1996) together with high levels of immunoreactivity, especially in the molecular layer. These discrepancies can be explained either by regional variations in the efficiency of translation and/or transcription of the 5- $\mathrm{HT}_{6}$ receptor gene, or by the transport of the receptor protein at some distance from its site of synthesis. Higher resolution immunocytochemistry was then performed in order to determine the cellular and ultrastructural localizations of $5-\mathrm{HT}_{6}$ receptors.

High Magnification Light Microscopy. In the hippocampus, $5-\mathrm{HT}_{6}$ receptor-like immunoreactivity was mainly found in the strata oriens and radiatum of the CA1 area and the molecular layer of the dentate gyrus oriens (Figure 1D). In contrast, the pyramidal and gran- 
ular cell layers were devoid of immunolabeling. This distribution, together with the presence of the corresponding mRNA in the latter two layers (Ward et al. 1995), indicates that $5-\mathrm{HT}_{6}$ receptors are probably transported from pyramidal and granular cell bodies to dendritic areas. In the caudate-putamen, $5-\mathrm{HT}_{6}$ receptorlike immunoreactivity is confined to the neuropil with no immunolabeling of cell bodies (Figure 1C). Previous in situ hybridization studies demonstrated the colocalization of the $5-\mathrm{HT}_{6}$ receptor mRNA with substance $\mathrm{P}$ and/or dynorphin mRNAs as well as enkephalin mRNA indicating that $5-\mathrm{HT}_{6}$ receptors are expressed by both striato-nigral and striato-pallidal efferent neurons (Ward and Dorsa 1996). Thus, it can be inferred that, in the striatum, $5-\mathrm{HT}_{6}$ receptors are probably located on dendrites of mixed GABAergic/peptidergic medium size spiny neurons that project to the substantia nigra or the globus pallidus. The absence of immunolabeling in the latter area is consistent with the addressing of $5-\mathrm{HT}_{6}$ receptors exclusively to the dendritic compartment of striato-pallidal neurons. On the other hand, $5-\mathrm{HT}_{6}$ receptor-like immunoreactivity in the substantia nigra could be due to receptors located on intrinsic neurons, as $5-\mathrm{HT}_{6}$ receptor mRNA has been detected in this structure by quantitative RT-PCR (Gérard et al. 1996). In both the striatum and the hippocampus, immunolabeling appeared to be associated only with neuronal elements, although expression of $5-\mathrm{HT}_{6}$ receptors by glial cells cannot be excluded (Hirst et al. 1997).

In addition to the diffuse immunolabeling of the neuropil, a more discrete punctate specific staining was observed in a few brain areas. At higher magnification, this staining appeared to correspond to immunolabeled elongated processes of $0.5 \mu \mathrm{m}$ or less width and ca. 10 $\mu \mathrm{m}$ length, especially in the nucleus accumbens, the caudate-putamen, the plexiform layer (layer 2) of the olfactory tubercles and the islands of Calleja (except the central hilus, Figures 2C and D). Nomarski interference contrast microscopy allowed the visualization of immunolabeled processes as short extensions emerging from cell bodies (Figure 2D).

Electron Microscopy. In both the striatum and the hippocampus, immunostaining at the electron microscope level was mainly associated with dendrites making synapses with unlabeled axon terminals (Figures 1E and F). Synaptic differentiations appeared more heavily labeled in the striatum, whereas in the hippocampus, dendritic profiles were generally filled with immunoreactivity. This ultrastructural localization of $5-\mathrm{HT}_{6}$ receptors confirmed that they are mainly addressed to the dendritic compartment. Accordingly, they might participate in 5-HT-mediated control of the discharge of neurones contacted by serotoninergic terminals.

Examination of the elongated immunoreactive processes already observed using high magnification light microscopy showed that immunolabeling did not include the initial segment that emerges from the cell body (Figure 2F). At this level, unlabeled microtubules could be observed, indicating that these immunoreactive processes have a typical ciliary structure. Indeed, cross sections of processes showed the expected nine doublet circular array of microtubules, but no doublet was found in the centre (Figure 2E). Cilia arising from neurons have been previously described in different regions of the brain (Peters et al. 1991). Thus, dopaminergic neurons in the ventral tegmental area (Bayer and Pickel 1990) and neuropeptide Y-immunoreactive neurons in the striatum (Wolfrum and Nitsch 1992) are known to possess cilia. In addition, a recent study demonstrated that the sst ${ }_{3}$ type of somatostatin receptors is also targeted to neuronal cilia in numerous regions in the rat brain (Händel et al. 1999). Like the 5- $\mathrm{HT}_{6}$-immunoreactive cilia (Figures 2E and F), those described in these previous studies also exhibit a configuration characteristic of non motile cilia where the central pair of microtubules is missing. Although cilia of central neurons can be vestigial and functionless, a sensory function might be postulated for these processes, by analogy with the retina where the outer segments of rods and cones are formed by modified and enlarged cilia (see Peters et al. 1991). In addition, olfactory cilia that also exhibit the typical non motile structure, are known to play a key role in olfaction through their expression of numerous G-protein-coupled receptors sensitive to odorants (Ronnett and Snyder 1992). Thus, it can be hypothesized that $5-\mathrm{HT}_{6}$ receptors on cilia would enable the ciliated neurons to sense the concentration of 5-HT in the immediate milieu. The striking feature of neuronal cilia endowed with $5-\mathrm{HT}_{6}$ receptor-like immunoreactivity is that only a few brain areas are concerned, suggesting that $5-\mathrm{HT}_{6}$ receptors might be involved in cilia-mediated functions only in these areas.

\section{Effects of I.C.V. Infusion of Antisense Oligonucleotide}

Stereological counting of $5-\mathrm{HT}_{6}$ receptor-like immunoreactive elements was made in the nucleus accumbens because previous data showed that this limbic structure is involved in anxiety-driven behaviours like those investigated in the present study (Ladurelle et al. 1995; Duncan et al. 1996). As expected of a decreased synthesis of $5-\mathrm{HT}_{6}$ receptors, the total number of $5-\mathrm{HT}_{6}$ receptor-like immunoreactive cilia in the nucleus accumbens ipsilateral to i.c.v. infusion was significantly lower $(-25 \%)$ in rats treated for four days with the antisense oligonucleotide $(1,060,637 \pm 44,450)$ than in those treated with the missense one $(792,983 \pm 33,957$; means \pm S.E.M., $n=5$ in each group, $p<.01$ ). In the nucleus accumbens of the contralateral hemisphere, antisense oligonucleotide-treatment also reduced significantly 

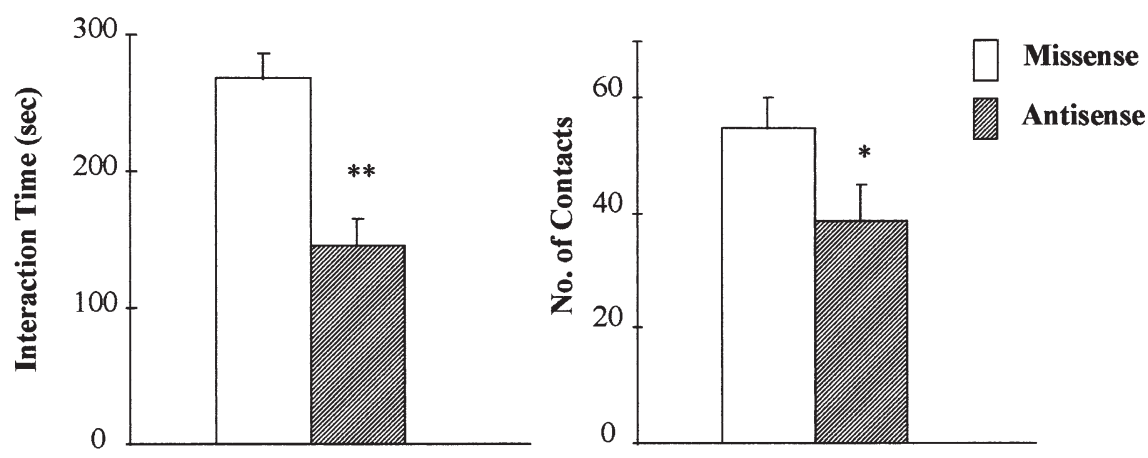

Figure 3. Effect of i.c.v. infusion (2.2 $\mu \mathrm{g} / \mu \mathrm{l} / \mathrm{hr}$ ) for four consecutive days of an antisense oligonucleotide specific of the $5-\mathrm{HT}_{6}$ receptor, or of a missense oligonucleotide, on the behaviour or rats in the social interaction test. Values are the means \pm S.E.M. of 10 pairs of rats. ${ }^{*} p<.05,{ }^{* *} p<.01$ as compared to rats treated with the missense oligonucleotide (Student's $t$-test).

the total number of cilia, by ca. $19 \%(p<0.01)$, as compared to that found in missense-treated rats.

Treatments with either antisense or missense oligonucleotide produced no effect on rectal temperature and daily food intake. A slight but non significant decrease in body weight $(-5-8 \%)$ could be observed after the surgical procedure, but there was no significant difference between the two group treatments. In contrast, paradigms designed to assess anxiety-driven behaviours revealed specific alterations in rats that had been treated with the antisense oligonucleotide. In the social interaction test under high light unfamiliar conditions, the four day-treatment with the antisense oligonucleotide significantly decreased both the time spent in social interaction and the number of contacts, as compared to control rats treated with the missense oligonucleotide (Figure 3). At this time point, the social interaction time of rats that had been i.c.v. infused with saline ( $239 \pm$ $12 \mathrm{sec}$, mean \pm S.E.M., $n=5$ ) did not significantly differ from that of animals treated with the missense oligonucleotide.

In the elevated plus-maze, the total number of entries into both types of arms for saline-treated controls was $13.4 \pm 2.1$ (mean \pm S.E.M., $n=6$ ), three days after the onset of i.c.v. infusion. This number was not changed by missense or antisense oligonucleotide treatment. The percentage of time spent in open arms by animals treated with saline or the missense oligonucleotide was $28.5 \pm 4.1$ (mean \pm S.E.M., $n=6$ ) and $26.3 \pm$ 3.8 (mean \pm S.E.M., $n=8$ ), respectively. This percentage was only $18.7 \pm 3.8$ (mean \pm S.E.M., $n=8$ ) for rats treated with the antisense oligonucleotide, indicating a significant decrease $(p<.05)$ as compared to the other two groups. The percentage of entries into the open arms also tended to be reduced in rats treated with the antisense oligonucleotide, but the difference did not reach statistical significance.

Quantification of the locomotor activity indicated that the distance traveled by control rats that had been i.c.v. infused with saline was $1296 \pm 112$ and $473 \pm 36$ $\mathrm{cm}$ (means \pm S.E.M., $n=6$ ) for the first and the second 15 min period, respectively. Similar values were found for rats that had been treated with the missense (1308 \pm
104 and $480 \pm 41 \mathrm{~cm}, n=5)$ or the antisense $(1246 \pm 156$ and $466 \pm 40, n=6$ ) oligonucleotide, indicating that these treatments did not affect locomotor activity.

These data indicated that chronic i.c.v. administration of an antisense oligonucleotide to decrease $5-\mathrm{HT}_{6}$ receptor expression in the rat brain (e.g., the nucleus accumbens) produced anxiogenic-like responses in two different paradigms. Phosphorothioate-modified oligonucleotides have frequently been reported to produce non specific effects suggestive of neurotoxicity such as elevated body temperature and suppressed food and water intake. However, such changes did not occur in the present study, and the small reduction in body weight which was observed in both antisense- and missense-oligonucleotide-treated rats could probably be ascribed only to the surgical procedure. Surprisingly, we did not observe the behavioural syndrome of yawning, stretching and chewing that has been reported to occur after repeated i.c.v. injections of antisense oligonucleotide (Bourson et al. 1995) or acute systemic administration of antagonists (Sleight et al. 1998) to decrease 5-HT action at $5-\mathrm{HT}_{6}$ receptors. Indeed, this behavioural syndrome was also not observed in a recent study using continuous i.c.v. administration of an antisense oligonucleotide (Yoshioka et al. 1998). In addition, homozygous mutant mice which do not express the $5-\mathrm{HT}_{6}$ receptor also exhibit no gross behavioral abnormalities and perform normally in a rotorod assay of motor coordination (Tecott et al. 1998). The different methods used for altering $5-\mathrm{HT}_{6}$ receptor function, acute or repeated treatments by Sleight and coworkers (Bourson et al. 1995; Sleight et al. 1998) versus continuous treatments in the present and other studies, may possibly account for the discrepancies.

\section{CONCLUSIONS}

Immunocytochemistry with specific polyclonal antibodies showed that $5-\mathrm{HT}_{6}$ receptors are mainly located in limbic (nucleus accumbens, olfactory tubercle, hippocampus) and some extrapyramidal (caudate-putamen, substantia nigra) areas in the rat brain. Their ad- 
dressing to the dendritic compartment suggests that they could mediate modulatory actions of 5-HT on the firing of neurons contacted by serotoninergic projections. In addition, in several brain areas (nucleus accumbens, islands of Calleja, olfactory tubercle, caudateputamen), $5-\mathrm{HT}_{6}$ receptors are located on neuronal cilia whose structure is typical of non motile cilia possibly involved in chemosensory functions. Previous studies showed that neither serotoninergic (Gérard et al. 1996) nor dopaminergic (unpublished observations) neurons are endowed with $5-\mathrm{HT}_{6}$ receptors. In contrast, GABAcontaining neurons in the striatum and glutamate-containing neurons in the hippocampus could be the targets of $5-\mathrm{HT}$ actions mediated by $5-\mathrm{HT}_{6}$ receptors. Whether these neurons participate in the anxiogeniclike behaviour resulting from the reduction in $5-\mathrm{HT}_{6}$ receptor expression in rats treated with specific antisense oligonucleotide is an open question for future investigations.

\section{ACKNOWLEDGMENTS}

These studies were supported by grants from INSERM, CNRS, and the European Commission (Contract Biotech BIO4 CT96 0752). We wish to thank Mrs. Claude Sais for excellent secretarial assistance and Drs. Marie-Jeanne Brisorgueil, Salah El Mestikawy, Caroline Gérard, A. Insausti, and Youssef Sari for their expert contributions to parts of these studies.

\section{REFERENCES}

Altschul SF, Warren Gish WM, Myers EW, Lipman DJ (1990): Basic logical alignment search tool. J Mol Biol 215:403-410

Baumgarten HG, Göthert M (1997): Serotoninergic Neurons and 5-HT Receptors in the CNS. Handbook of Experimental Pharmacology, vol. 129. Berlin, Springer-Verlag

Bayer VE, Pickel VM (1990): Ultrastructural localization of tyrosine hydroxylase in the rat ventral tegmental area: Relationship between immunolabeling density and neuronal associations. J Neurosci 10:2996-3013

Boess FG, Monsma FJ Jr, Carolo C, Meyer V, Rudler A, Zwingelstein C, Sleight AJ (1997): Functional and radioligand binding characterization of rat $5-\mathrm{HT}_{6}$ receptors stably expressed in HEK293 cells. Neuropharmacology 36:713-720

Bourson A, Borroni E, Austin RH, Monsma FJ Jr, Sleight AJ (1995): Determination of the role of the 5-ht $\mathrm{t}_{6}$ receptor in the rat brain: A study using antisense oligonucleotides. J Pharmacol Exp Ther 274:173-180

Branchek TA, Zgombick JM (1997): Molecular biology and potential functional role of $5-\mathrm{HT}_{5}, 5-\mathrm{HT}_{6}$, and $5-\mathrm{HT}_{7}$ receptors. In Baumgarten HG, Göthert M (eds), Serotoninergic Neurons and 5-HT Receptors in the CNS, Handbook of Experimental Pharmacology, vol 129. Berlin, Springer-Verlag, pp 475-497

Duncan GE, Knapp DJ, Breese GR (1996): Neuroanatomical characterization of Fos induction in rat behavioral models of anxiety. Brain Res 713:79-91

El Mestikawy S, Riad M, Laporte AM, Vergé D, Daval G, Gozlan H, Hamon M (1990): Production of specific antirat $5-\mathrm{HT}_{1 \mathrm{~A}}$ receptor antibodies in rabbits injected with a synthetic peptide. Neurosci Lett 118:189-192

File SE (1980): The use of social interaction as a method for detection of anxiolytic activity of chlordiazepoxide-like drugs. J Neurosci Meth 2:219-238

Gérard C, El Mestikawy S, Lebrand C, Adrien J, Ruat M, Traiffort E, Hamon M, Martres MP (1996): Quantitative RT-PCR distribution of serotonin $5-\mathrm{HT}_{6}$ receptor mRNA in the central nervous system of control or 5,7-dihydroxytryptamine-treated rats. Synapse 23:164-173

Gérard C, Martres MP, Lefèvre K, Miquel MC, Vergé D, Lanfumey L, Doucet E, Hamon M, El Mestikawy S (1997): Immuno-localization of serotonin $5-\mathrm{HT}_{6}$ receptor-like material in the rat central nervous system. Brain Res 746:207-219

Grimaldi B, Bonnin A, Fillion MP, Ruat M, Traiffort E, Fillion

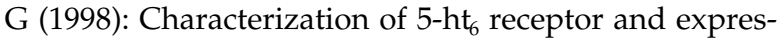
sion of $5-\mathrm{ht}_{6}$ mRNA in the rat brain during ontogenetic development. Naunyn-Schmiedeberg's Arch Pharmacol 357:393-400

Gundersen HGJ, Jensen EB (1987): The efficiency of systematic sampling in stereology and its prediction. J Microscopy 147:229-263

Händel M, Schulz S, Stanarius A, Schreff M, ErdtmannVourliotis M, Schmidt H, Wolf G, Höllt V (1999): Selective targeting of somatostatin receptor 3 to neuronal cilia. Neuroscience 89:909-926

Hirst WD, Price GW, Rattray M, Wilkin GP (1997): Identification of 5-hydroxytryptamine receptors positively coupled to adenylyl cyclase in rat cultured astrocytes. Br J Pharmacol 120:509-515

Hoyer D, Clarke DE, Fozard JR, Hartig PR, Martin GR, Mylecharane EJ, Saxena PR, Humphrey PPA (1994): VII. International Union of Pharmacology Classification of Receptors for 5-Hydroxytryptamine (Serotonin). Pharmacol Rev 46:157-203

Kohen R, Metcalf MA, Khan N, Druck T, Huebner K, Lachowicz JE, Meltzer HY, Sibley DR, Roth BL, Hamblin MW (1996): Cloning, characterization, and chromosomal localization of a human $5-\mathrm{HT}_{6}$ serotonin receptor. J Neurochem 66:47-56

Ladurelle N, Roques BP, Daugé V (1995): The transfer of rats from a familiar to a novel environment prolongs the increase of extracellular dopamine efflux induced by CCK8 in the posterior nucleus accumbens. J Neurosci 15:3118-3127

Max SI, Monsma FJ Jr, Sibley DR (1995): Agonist-induced desensitization of $5-\mathrm{HT}_{6}$ serotonin receptor-coupled adenylyl cyclase in stably transfected HEK-293 cells. J Serotonin Res 2:101-116

Michel RP, Cruze-Orive LM (1988): Application of the Cavalieri principle and vertical sections method to lung: estimation of volume and pleural surface area. J Microscopy 150:117-136

Monsma FJ Jr, Shen Y, Ward RP, Hamblin MW, Sibley DR (1993): Cloning and expression of a novel serotonin 
receptor with high affinity for tricyclic psychotropic drugs. Mol Pharmacol 43:320-327

Pellow S, Chopin P, File SE, Briley M (1985): Validation of open-closed arm entries in an elevated plus maze as a measure of anxiety in the rat. J Neurosci Meth 14:149167

Peters A, Palay SL, Webster HF (1991): The Fine Structure of the Nervous System. Oxford, Oxford University Press

Ronnett GV, Snyder SH (1992): Molecular messengers of olfaction. Trends Neurosci 15:508-513

Roth BL, Craigo SC, Choudhary MS, Uluer A, Monsma FJ Jr, Shen Y, Meltzer HY, Sibley DR (1994): Binding of typical and atypical antipsychotic agents to 5-hydroxytryptamine-6 and 5-hydroxytryptamine-7 receptors. J Pharmacol Exp Ther 268:1403-1410

Ruat M, Traiffort E, Arrang JM, Tardivel-Lacombe J, Diaz J, Leurs R, Schwartz JC (1993): A novel rat serotonin (5$\mathrm{HT}_{6}$ ) receptor: Molecular cloning, localization and stimulation of cAMP accumulation. Biochem Biophys Res Commun 193:268-276

Sleight AJ, Boess FG, Bös M, Levet-Trafit B, Riemer C, Bourson A (1998): Characterization of Ro 04-6790 and Ro 630563: Potent and selective antagonists at human and rat 5- $\mathrm{HT}_{6}$ receptors. Br J Pharmacol 124:556-562

Sterio DC (1984): The unbiased estimation of number and size of arbitrary particles using the disector. J Microscopy 134:127-136
Tecott LH, Chu HM, Brennan TJ (1998): Neurobehavioral analysis of $5-\mathrm{HT}_{6}$ receptor null mutant mice. Abstr. S 1.2 (23). 4th IUPHAR (International Union of Pharmacology) Satellite Meeting on Serotonin, Rotterdam, July 1998

Ward RP, Dorsa DM (1996): Colocalization of serotonin receptor subtypes $5-\mathrm{HT}_{2 \mathrm{~A}}, 5-\mathrm{HT}_{2 \mathrm{C}}$, and $5-\mathrm{HT}_{6}$ with neuropeptides in rat striatum. J Comp Neurol 370:405-414

Ward RP, Hamblin MW, Lachowicz JE, Hoffman BJ, Sibley DR, Dorsa DM (1995): Localization of serotonin subtype 6 receptor messenger RNA in the rat brain by in situ hybridization histochemistry. Neuroscience 64:11051111

West MJ, Ostergaard K, Andreassen OA, Finsen B (1996): Estimation of the number of somatostatin neurons in the striatum: an in situ hybridization study using the optical fractionator method. J Comp Neurol 370:11-22

Wolfrum G, Nitsch C (1992): High frequency of ciliated neuropeptide $\mathrm{Y}$ immunoreactive neurons in rat striatum. Cell Tissue Res 267:199-202

Yoshioka M, Matsumoto M, Togashi H, Mori K, Saito H (1998): Central distribution and function of 5- $\mathrm{HT}_{6}$ receptor subtype in the rat brain. Life Sci 62:1473-1477

Zhou M, Grofova I (1995): The use of peroxidase substrate Vector VIP in electron microscopic single and double antigen localization. J Neurosci Meth 62:149-158 